\title{
Impact of Financial Leverage, Size and Assets Structure on Firm Value: Evidence from Industrial Sector, Jordan
}

\author{
Zaher Abdel Fattah Al-Slehat $^{1}$ \\ ${ }^{1}$ Assistant professors: Faculty of Business, Tafila Technical University, Jordan \\ Correspondence: Zaher Abdel Fattah Al-Slehat, Tafila Technical University, At-Tafila, P.O. Box 179, Tafila, \\ 66110 , Jordan.
}

Received: November 11, 2019

Accepted: December 4, 2019 Online Published: December 10, 2019

doi:10.5539/ibr.v13n1p109

URL: https://doi.org/10.5539/ibr.v13n1p109

\begin{abstract}
The present study aims at revealing the financial leverage, Size, and asset structure and its impact on the values of firms. The researcher used the analytical method approach for a sample of 13 firms from the mining and extraction industry sector listed on the Amman stock exchange of the period 2010-2018. The model of simple line regression was used for testing the hypotheses of the study by using both programs of (E-views, STATA) in addition to both programs of unit root test and variance inflation factor to make sure of the data stability and no relationship between variables.

The study concluded the non-existence of the impact of financial leverage on the firm value and the relationship between the financial leverage and Tobin's q scale was negative. However, there was an impact of each size and asset structure on firm value and the relationship between the natural logarithm of size and asset structure was positive with Tobin's q. The study recommends that Companies must achieve an optimal mixture of debt and equity, for long-term survival and hence the growth of the company.
\end{abstract}

Keywords: financial leverage, size, assets structure, firm value

\section{Introduction}

Financial leverage and firm size have considered the most important issues which concern financial managers as a result of the enormous development which the financial market undergoes and the technological development in the use of financial resources, which have allowed accomplishing the advantage of the variety of these resources. This requires the increase of concern about both decisions of financing and investment, in a way that realizes a current of positive future profits, and consequently, the rise of stock prices in the market, namely, the increase in the wealth of owners.

On the other hand, (Noghondari \& Noghondari, 2017) refer to the financial leverage is one of the most difficult issues that face the financial manager when taking a decision, because the increase in the debt ratio may increase the financial risks and lead to the rise of capital cost. Accordingly, firms should improve the use of financial resources in a way that leads to an increase in profitability.

The Jordanian mining and extraction industry sector works in light of an environment characterized by competition at both local and international levels. Therefore, this sector needs more technological intensity than the other sectors. The fact which forces the financial management to be successful to mix between financing by debt and equity, concerning quantity and quality, in a way that reflects on the achievements of its future aims.

The main aim of present study is to study the nature and direction of the relationship between each of financial leverage, size, assets structure and firms value. And the impact of financial leverage, size, and assets structure of the firm's value.

Financial Leverage is important in the mining and extraction industry sector, to finance its assets and thus increase shareholder value. Therefore, this study is important for the Jordanian economy, which was affected by the global financial crisis. As the Amman stock financial market helps to increase investment, create employment opportunities, increase economic growth and attract local and foreign investments. Thus, this topic will be focused on academics and researchers to help this sector. 


\section{Theoretical Framework and Previous Studies}

\section{Financial leverage}

Financial leverage is the use of debt in a firm's capital structure, when firms take their financial decision, they should take into consideration the capital structure as it influences the mixture of debt and equity, and consequently, the influence on the earnings and risks of shareholders. The mixture of debt and equity can be determined by the help of financial leverage. (Jiricek \& Dostalova, 2010) pointed out that money can be obtained through issuing bonds, bank loans or issuing more earnings per share. And is the degree to which a firm has funded its business operations through external resourced (Modigliani \& Miller, 1958). (Myers, 2002) indicates that the use of a raised level of debt has the advantage of the tax-saving, which improves profitability, but this can also lead to the likelihood of being taken over by the creditor. (Mule \& Mukras, 2015)

Financial leverage is represented in the process of using debts (Borrowing) within the financial structure or the loan whose surplus can be re-invested in order to obtain more earnings. (Raheel \& Shah, 2015)

(Akpinar, 2016; Senol et al., 2017; Ahmad et al., 2015; Al-Malkawi, 2008; Chikalipah, 2019; Raza 2013; Al-Rdaydeh et al., 2018) indicated that the financial leverage can be calculated by using the following equation:

Financial leverage $=$ Total Debt $/$ Total Equity

Financial leverage $=$ Total Debt $/$ Total Assets

And (Pandey 2015) pointed out The financial leverage is measured by the following indicators:

1. The ratio of debt to equity capital.

2. The ratio of debt to total capital.

3. The ratio of fixed charges to net operating income.

(Agwan, 2015; Rayan, 2008) pointed out that the decision of financial leverage emphasizes the apportionment between debt and equity in financing the firm in light of an environment characterized by uncertainty in regard to future cash flows.

\section{company size}

The firm size is considered as one of the basic restrictive things in both small and big firms at the local and foreign levels when taking decisions relating to financial leverage. (Faccio et al., 2016) pointed out that the total assets are the total fixed assets (tangible and intangible assets and other fixed assets), and current assets (inventory, receivable and other current assets). For determining the firm size, the natural logarithm of the total assets will be used. (Panaretou, 2014; Ayturk et al, 2016; Aggarwal \& Padhan, 2017).

Usually, the big firms are more diversified and less risky and the earning per share is connected with size and is positively connected with the ratio of the market value to the book value, a lot of researches have revealed that the relationship between size and financial earnings are similar concerning financial and non-financial firm. (Liow, 2010)

\section{Assets structure}

Assets structure is one of the aspects relating to the firm resources which describe the assets structure, like the fixed assets, current assets, they are the ownerships of the firm at a certain time for a certain period that can be measured through the following equation: (Desmintari \& yetty, 2016; Machali \& Setiadharma, 2017; Ukhriyawati et al., 2017).

1. The percentage of current assets to total assets.

2. The percentage of fixed assets to total assets.

3. Other assets ratio to total assets.

(Al-Ani, 2014; Ukhriyawati et al., 2017) pointed out that assets structure is a group of tangible assets of the firm in establishing and expanding its tasks and using them in its operations, the tangible assets must be used as insurance to get debt finance from the bank as lenders (Myers, 1977). According to (Titman \& Wessels, 1988; Harris \& Raviv, 1991) asset tangibility are the main factor in deciding the firm's debt level, and the empirical studies have shown that the assets tangibility is positively related to debt ratio. (Friend \& Lang, 1988; Rajan \& Zingales, 1995; Williamson, 1988).

value of the company

Interest in the firm's value has become an important element in the analysis; several previous studies have 
indicated that the value of the company is influenced by the following factors: (Machali \& Setiadharma, 2017)

1. Firm value is affected by asset structure: Assets are property or property owned by the company in a certain period. There are two types of assets: current assets and fixed assets. The ratio of those assets will determine the firm asset structure.

2. Firm value is affected by firm size. The total assets owned by a firm indicate the firm size. The bigger the firm size, the easier it is to get internal or external sources of funds, which will affect the firm value itself .

3. Firm value is affected by capital structure: The first thing that has to be done by firm management is to understand fully the main components of capital structure. An optimum capital structure is the one which maximizes the stock price. Excessive loans may detain the firm developed and make the shareholder think twice before investing.

(Sabrin et al., 2016; Moeljadi, 2014) indicated that the main aim of the firm owners is to maximize the firm value as it implies the prosperity of shareholders or investors. Seeking the increase of the firm value may face the agency problem. The firm value is influenced by internal factors such as the factors of financial decisions, dividend policy and external factors such as economic growth, interest rates, Foreign Exchange Rates.

The firm value has been measured through Tobin's q equation which is one of the most widely spread measures for determining the firm value. It's known as the market value of the firm divided by the book value of assets or the book value or the owners' equity. (Kim et al., 2015)

The study of (Fu et al., 2016) pointed out that Tobin's q equation indicates that the market value of the firm divided by the replacement value of the firm assets. (Lindneberg \& Ross, 1981) pointed out that the replacement value of the firm can be expressed by the following equation:

$\mathrm{RCt}=\mathrm{Tat}+\mathrm{RNPt}-\mathrm{HNPt}+\mathrm{RINVt}-\mathrm{HINVt}$

Where is the:-

RCt: Replacement cost.

Tat: Total assets per year $\mathrm{t}$.

RNPt: The net value of the equipment and machinery at replacement cost per year $t$.

HNPt: The net value of historical equipment and machinery.

RINVt: The net replacement cost of inventory value per year $t$.

HINVt: The net value of inventory of historical value per year $t$.

To avoid the problem of the unavailability of the information relating to the population of the study, the approximation of Tobin's q was used which is measured as follows:

Tobin's Q Approximation = $(\mathrm{TMV}+\mathrm{PS}+\mathrm{DEBT}) / \mathrm{TA}$

TMV: The Company's market value.

PS: preferred stock.

DEBT: The Accounting value of the company's indebtedness.

TA: The Accounting value at the end of the year of the company's total assets.

Where the value of Tobin's q is greater than the one it shows that the market values of the firm's assets are greater than actual cost which signify that the firm's position is good and vice versa. (Chung \& Pruitt, 1994; Gill \& Obradovich, 2013)

\subsection{Previous Studies}

The study of Dutta et al., (2018) examined the impact of financial leverage on the firm's value for a sample of 31 companies listed in New York stock exchange for six different sectors for ten years. The study concluded the existence of a big negative relationship between the degree of financial leverage and the firm's value after the control of the changing size of the firm.

Ishari, (2016) investigated the impact of financial leverage on the values of firms for the period 2011-2015 for a sample of ten industrial firms listed in the Sri Lanka market, the results indicated the existence of a reverse relationship between financial leverage and firms' value, the study proved that financial leverage did not have an impact on the firm's value.

On the other hand, cheryta et al., (2017) aimed at the analysis of the impact of financial leverage and profitability 
and inconsistency of information and cash, possessions on the firm's value for a sample of 56 firms listed on Indonesia stock exchange for the period 2012-2015. The results indicated that financial leverage had a negative impact on cash positions and profitability had a positive impact on cash positions and the firm's value. The study concluded the non-existence of the impact of financial leverage and the size of the firm's value.

Bestariningrum, (2015) explored the effect of capital structure and firm size on the firm's value of the firms listed in the LQ-45 indicator for the period (2010-2014), for a sample of 42 companies. The study concluded that capital structure and firm size had a positive and important impact on the firm's value.

The study of Ayuba et al., (2019) aimed at testing the impact of financial performance, capital structure and firm size on the value of firms for a sample of 27 insurance companies listed on a Nigeria stock exchange for six years from 2012-2017. The study concluded that all variables had an impact on the value of insurance companies in Nigeria.

The study of (Machali \& Setiadharma, 2017) aimed at testing the impact of asset structure and size of the firm's value for a sample of 34 estate firms in Indonesian stock exchange for the period 2010-2014. The study concluded the existence of a direct impact on the asset structure of the firm's value and it concluded the non-existence of impact of size on the firm's value.

However, (Farooq \& Masood, 2016) studied the impact of financial leverage on the value of firms in the cement sector in Pakistan for the period 2008-2012 for a sample of 19 firms. The study concluded the existence of a statistically positive and important correlation between financial leverage and firm's value expressed by Tobin's $\mathrm{q}$ scale.

Finally, the study of Collins et al., (2012) aimed at revealing the impact of the firm's capital structure on its market value for a sample of 19 non-financial firms for the period 2005-2009. The study concluded a group of results, the most important of which was the existence of a positive impact on the firm's size of its market value.

\subsubsection{Study Contribution}

Through the review of literature, no study has dealt with the four dimensions combined together represented in (financial leverage, size, assets structure and firm value). Therefore, what distinguishes the study, to the researcher's knowledge, is the fact that it combined four variables which are very important in the science of financing for two sides: the applications side as the financial leverage forms one of the basic pillars in taking the financial decisions. And the practical side as the four dimensions represented in financial leverage, size assets structured and firm's value is the concern of researchers.

\section{Methodology}

\subsection{Research Hypotheses}

H01: There is no impact of the financial leverage on firm value.

Ho2: There is no impact of size on firm value.

$\mathrm{H} 03$ : There is no impact of the asset structure on firm value.

\subsection{Population and Sample Study}

The populations of the present study consist of all company mining and extraction industry listed on the Amman Stock Exchange for the period from 2010 to 2018. While the sample consists of 13 firms based on the following conditions:

1. All required data are available.

2. No merger process between firms.

3. The fiscal year ends on the $31 / 12$.

4. The financial reports for all firms are available.

\subsection{Data Collection}

The annual financial reports of sample firms, the reports issued by the Amman Stock Exchange, books, periodicals, Journals, and related references are used, in addition to studies, articles, master theses and doctoral dissertations published on the internet.

\subsection{Model of Study}

For dealing with the variables of the study and achieving its aim, the study of (Al-Malkawi, 2008; Chikalipah, 2019; Raza, 2019) was used for the independent variable, represented in financial leverage. And the studies of 
(Ayturk et al, 2016; Akpinar, 2016; Senol et al., 2017) were used for the size variable. For asset structure, the studies of (Al-Ani, 2014; Noghondari \& Noghondari 2017; Ukhriyawati et al., 2017). The dependent variable represented in the value of the firm which was measured through Tobin's q equation for that the studies of (Fu et al., (2016); Chung \& Pruitt, (1994) were used.

Through the review of previous studies, the model of the current study can be divided into the following:

3.4.1 The Quantitative Model of the Study

By reviewing the models used in the previous studies which can be used for testing the hypotheses of the study, the following models can be formed:

Model 1: Tobin's q $=\alpha+\mathrm{B} 1 \mathrm{FL}+\mathrm{e}$

Model 2: Tobin's q $=\alpha+$ B1Logs $+\mathrm{e}$

Model 3: Tobin's q $=\alpha+\mathrm{B} 1 \mathrm{AS}+\mathrm{e}$

\subsubsection{The Qualitative Model of the Study}

The following model reflects the specific concepts of the nature of the problem and its signs relating to the test of the impact of financial leverage, size, and asset structure to the value of the firm.

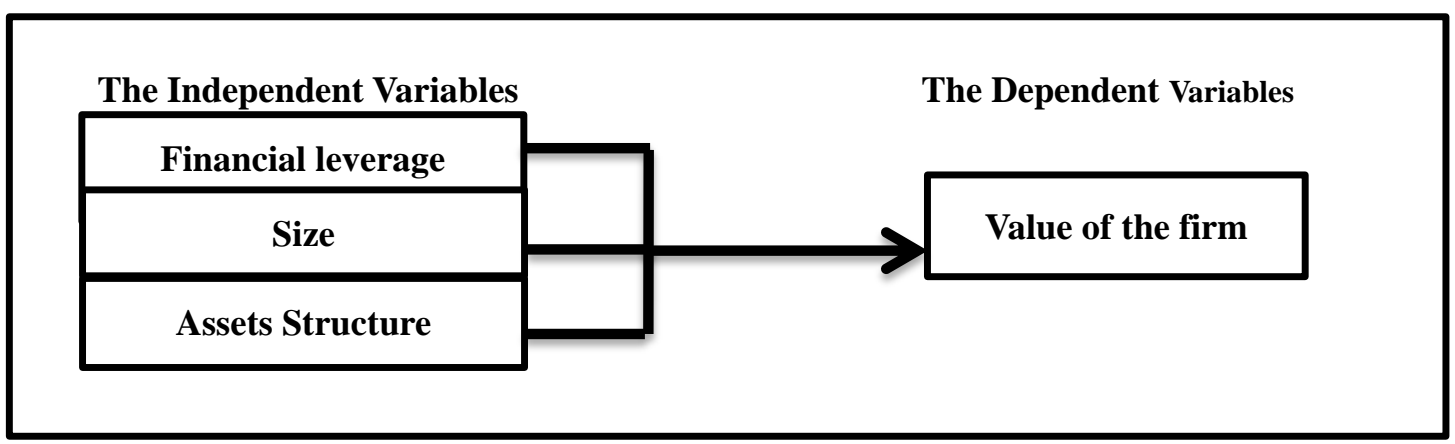

Figure 1. The qualitative model of the study

\subsection{Study Variables}

3.5.1 The Independent Variables

Financial leverage $(\mathrm{FL})=$ Total debt (D) / Total Equity (E).

Size (Log size): it is computed as the natural logarithm of total assets.

Assets Structure (AS): The percentage of fixed assets to total assets.

\subsubsection{The Dependent Variable}

Approximate Tobin's q= $(\mathrm{MVE}+\mathrm{PS}+\mathrm{DEBT}) / \mathrm{TA}$

\section{The Statistical Analysis}

\subsection{The Descriptive Analysis}

Tables $(1,2,3,4)$ explains the mean and standard deviation of the independent variables.

Table 1. Descriptive analysis of FL

\begin{tabular}{|c|c|}
\hline & $F L$ \\
\hline Mean & 1.461 \\
\hline Median & 0.973 \\
\hline Standard Deviation & 2.250 \\
\hline Sample Variance & 5.063 \\
\hline Kurtosis & 17.612 \\
\hline Skewness & 3.974 \\
\hline Range & 14.602 \\
\hline Sum & 170.995 \\
\hline Count & 117 \\
\hline
\end{tabular}




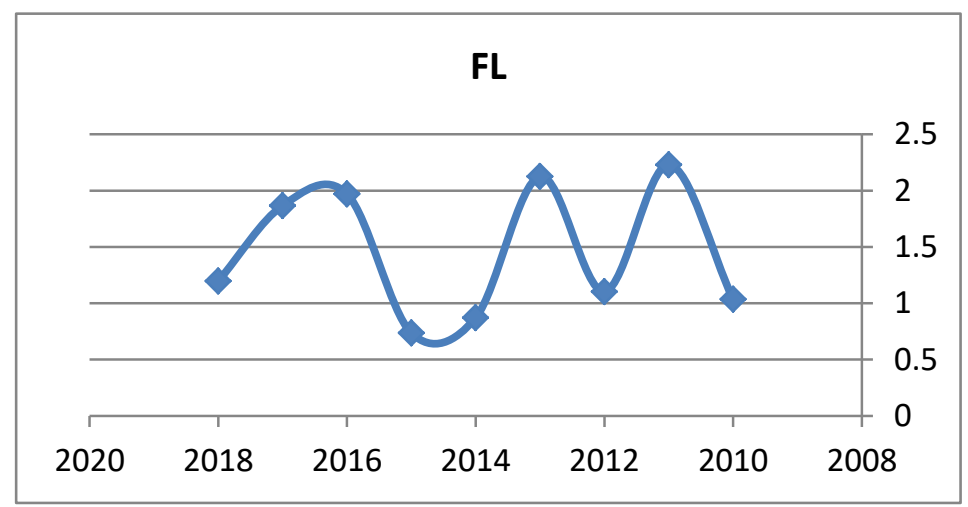

Figure 2. The development of financial leverage during the year of study

Table (1) explains the descriptive analysis of the financial leverage. While the mean was (1.461), with a standard deviation of (2.250).

Figure (2) presents the development of the financial leverage during the study period. This indicates that the examined and analyzed a sample of the study is moderate and close in its dependence on financial leverage.

Table 2. Descriptive analysis of $\log \mathrm{s}$

\begin{tabular}{|c|c|}
\hline & Size \\
\hline Mean & 9.308 \\
\hline Median & 9.287 \\
\hline Standard Deviation & 0.424 \\
\hline Sample Variance & 0.179 \\
\hline Kurtosis & 1.180 \\
\hline Skewness & 1.053 \\
\hline Range & 1.9346 \\
\hline Sum & 1089.076 \\
\hline Count & 117 \\
\hline
\end{tabular}

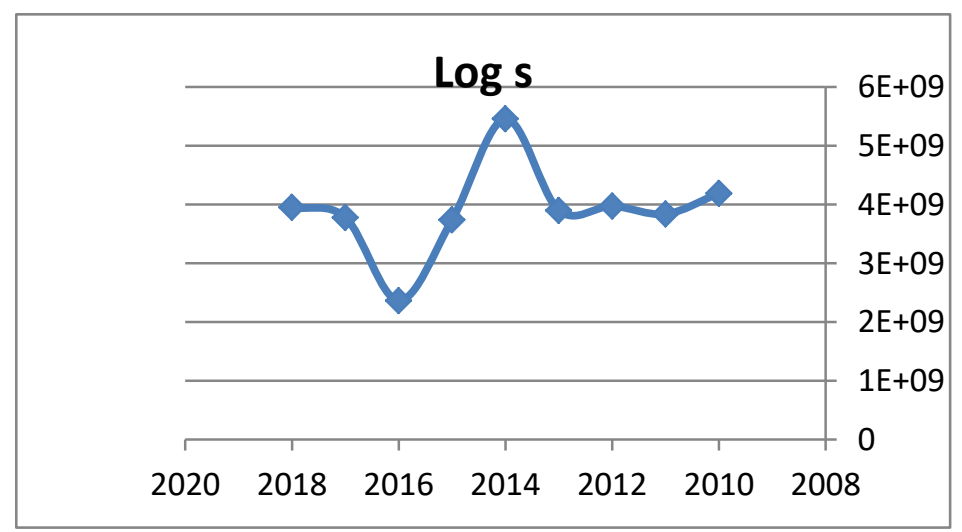

Figure 3. The development of size during the year of the study

Table (2) shows the descriptive analysis of the size. While the arithmetic mean of size was (9.308), with a standard deviation of $(0.424)$.

Figure (3) presents the development of the size during the study period. This signifies the existence of differences between the firms as a testing sample about their size being big, medium and small. 
Table 3. Descriptive analysis of AS

\begin{tabular}{|c|c|}
\hline & AS \\
\hline Mean & 109753724 \\
\hline Median & 11065462 \\
\hline Standard Deviation & 266487892 \\
\hline Sample Variance & 7.1015 \\
\hline Kurtosis & 8.059 \\
\hline Skewness & 3.052 \\
\hline Range & 1222948860 \\
\hline Sum & 12841185803 \\
\hline Count & 117 \\
\hline
\end{tabular}

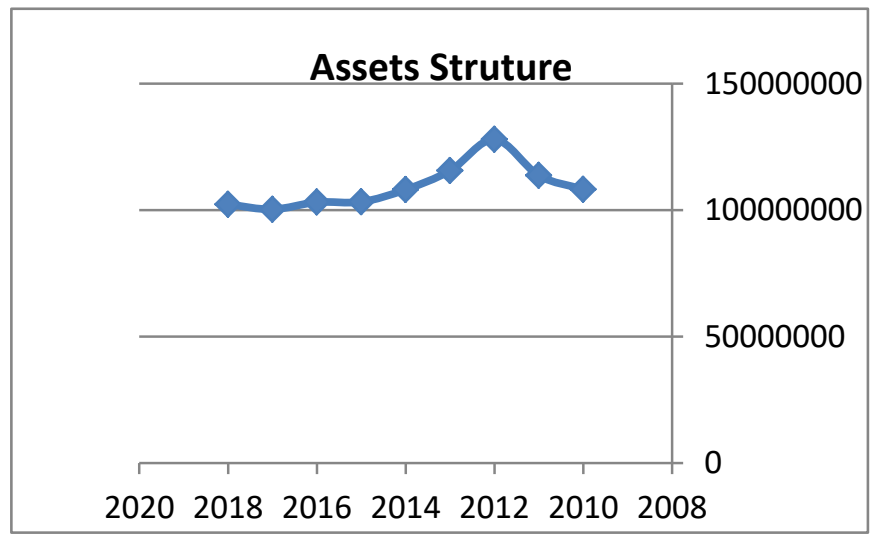

Figure 4. The development of Assets structure during the year of study

Table (3) shows the descriptive analysis of the size. While the arithmetic mean of assets struture was (109753724), with a standard deviation of (266487892).

Figure (3) presents the development of the assets struture during the study period. The asset structure signifies the approximate ownership of assets.

Table 4. Descriptiv analysis of Tobin's q

\begin{tabular}{|c|c|}
\hline & Tobin's $q$ \\
\hline Mean & 0.988 \\
\hline Median & 0.971 \\
\hline Standard Deviation & 0.182 \\
\hline Sample Variance & 0.0332 \\
\hline Kurtosis & 10.115 \\
\hline Skewness & 0.255 \\
\hline Range & 1.829 \\
\hline Sum & 115.67 \\
\hline Count & 117 \\
\hline
\end{tabular}




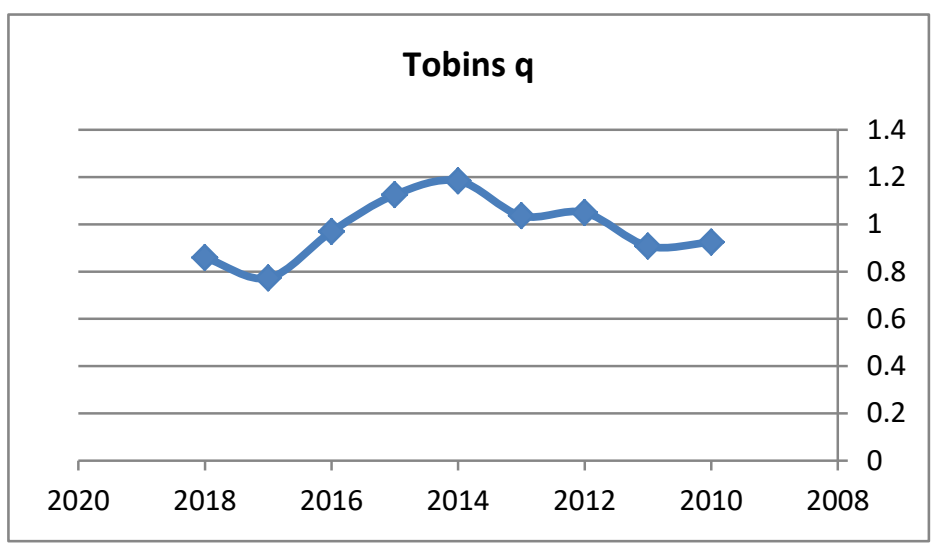

Figure 5. The development of Tobin's q during the year of study

Finally, Table (4) shows the descriptive analysis of the Tobin's q. While the mean of size was (0.988), with a standard deviation of $(0.182)$.

Figure (4) presents the development of the Tobin's q during the study period. This signifies the existence of simple differences in the values examined and analyzed firms resulting from differences in their sizes and age besides the difference in their market shares.

\subsection{Unit Root Test}

Table (5) shows the Unit Root Test, Levin-Lin-Chu test. The P-value was less than 5\% for all variables, and consequently, all the independent and dependent variables were characterized by stability during the years of examining and analyzed the study.

Table 5. Unit Root Test

\begin{tabular}{ccc}
\hline Variables & P-value & t-statistic \\
\hline FL & 0.00 & -11.2898 \\
Logs & 0.00 & -8.00849 \\
AS & 0.00 & -3.73201 \\
Tobin's q & 0.00 & -2.28411 \\
\hline
\end{tabular}

\subsection{Multicollinearity Test Results Between Independent Variables}

Table 6. Variance Inflation Factor

\begin{tabular}{cc}
\hline Variables & VIF \\
\hline FL & 1.042 \\
Logs & 1.220 \\
AS & 1.236 \\
\hline
\end{tabular}

The previous table shows that the values (VIF) (variance inflation factor) for all the independent variables are less than 5. This indicates the non-existence of a multiple linear correlation problem between the study variables.

\subsection{Results of Testing Hypotheses and Discussion}

The First hypothesis: There is no impact of the financial leverage on firm value.

Table (7) presents the results of the simple regressions related to the first hypothesis of the study. The value of Durbin-Watson test (1.63) indicates that there is no autocorrelation between the errors in the regression equation, within the acceptable limits for this test. Thus, according to the calculated value of T-test (-1.737696) which is less than the tabulated value of T-test (1.960), thus, this hypothesis is accepted, which signifies the fact about the non-existence of the impact of financial leverage on the firm value at significance level 0.086 which is greater than 0.05 T-test value indicates the existence of a negative relationship between the financial leverage and the value of the firm.

The table showed that that the coefficient value $\left(\mathrm{R}^{2}\right)=(0.58)$, which means that the financial leverage is able to explain 0.56 of changes occurred in firm value. 
The result of testing the first main hypothesis indicates the following:

1. With the other factors remaining stable, the examined and analyzed study sample avoids the use of financial leverage for the sake of increasing the value of the firm.

2. Managerial leaderships have a group of other factors which have something to do with the value of the firm such as size and asset structure.

3. This result proves that the use of much financial leverage bears the financing cost of the firm represented interest on debts.

The second hypothesis: There is no impact of size on firm value.

Table (7) presents the results of the simple regressions related to the second hypothesis of the study, the value of Durbin-Watson test (2.40) which is within the accepted limits of this test. The calculated value of T-test (2.953141) is bigger than the tabulated value of T-test (1.960) with a significance level $(0.0006)$ which is less than 0.05 . The value of the T-test indicates the existence of a positive relationship between size and firm value.

Based on that, the null hypothesis is rejected and the alternative hypothesis is accepted which implies the fact of the existence of size impact on the firm's value.

The table presented that the coefficient value $\left(R^{2}\right)=(0.60)$ that refers the size clarifies $(0.60)$ of changes in firm value.

The results of testing the main second hypothesis indicate the following:

1. It appears through the analysis of the second hypothesis that firms tend to size in the choice of financial resources in a perfect way to increase their value and not only depend on financial leverage which bears the additional cost for them.

2. The positive impact of the increase company size will lead to an increase in its value.

The third hypothesis: There is no impact of the asset structure on firm value.

The results of testing the third hypothesis of the study as shown in table (7) indicate the results of simple regression where the value of Durbin-Watson was (2.39) the value indicates that there is no autocorrelation between the errors in the regression equation within the acceptable limits for this test. And based on the calculated value of the T-test (3.432478) which is greater than the tabulated value of the T-test (1.960). The value of the T-test indicates the existence of a positive relationship between asset structure and the value of the firm.

However, the results refer to reject the null hypothesis and accept the alternative hypothesis which said: There is an impact of the asset structure on firm value. with a significance level of $(0.0009)$ which is less than $(0.05)$.

The table presented that the value of the coefficient $\left(R^{2}\right)=(0.61)$ which that the size explains 0.61 of changes in firm value.

The result of testing the third main hypothesis shows the following:

1. Increased asset structure, leading to increase the ability of companies to choose the optimal structure of debt and equity.

2. The positive impact caused by assets structure to the value of firms reinforces what was reached in the first hypothesis. This is an indication that the examined and analyzed firms avoid the use of financial leverage for increasing their value, the fact which means their direction toward finance resources other than financing by debt depending on their assets structure.

3. The positive impact of the increase assets structure will lead to an increase in its value.

We notice that the result of the first hypothesis relating to the impact of financial leverage on the value of the firm's conformed to the studies of (Cheryta et al, 2017; Ishari, 2016; Dutta et al., 2018) and was different from the study of (Farooq and Masood, 2016) in regard to the relationship. Concerning the second hypothesis of the study relating to the impact of size on the firm's value, it conformed with (Bestariningrum, 2015; Ayuba, et al., 2019; Collins et al., 2012) and was different from the study of (Cheryta et al., 2017; Setiadharma \& Machali, 2017; Farooq \& Masood, 2016). The third hypothesis relating to the impact of the assets structure on the firm's value conformed to the study of (Setiadharma \& Machali, 2017). 
Table 7. The results of the simple regression analysis of the financial leverage, size and asset structure

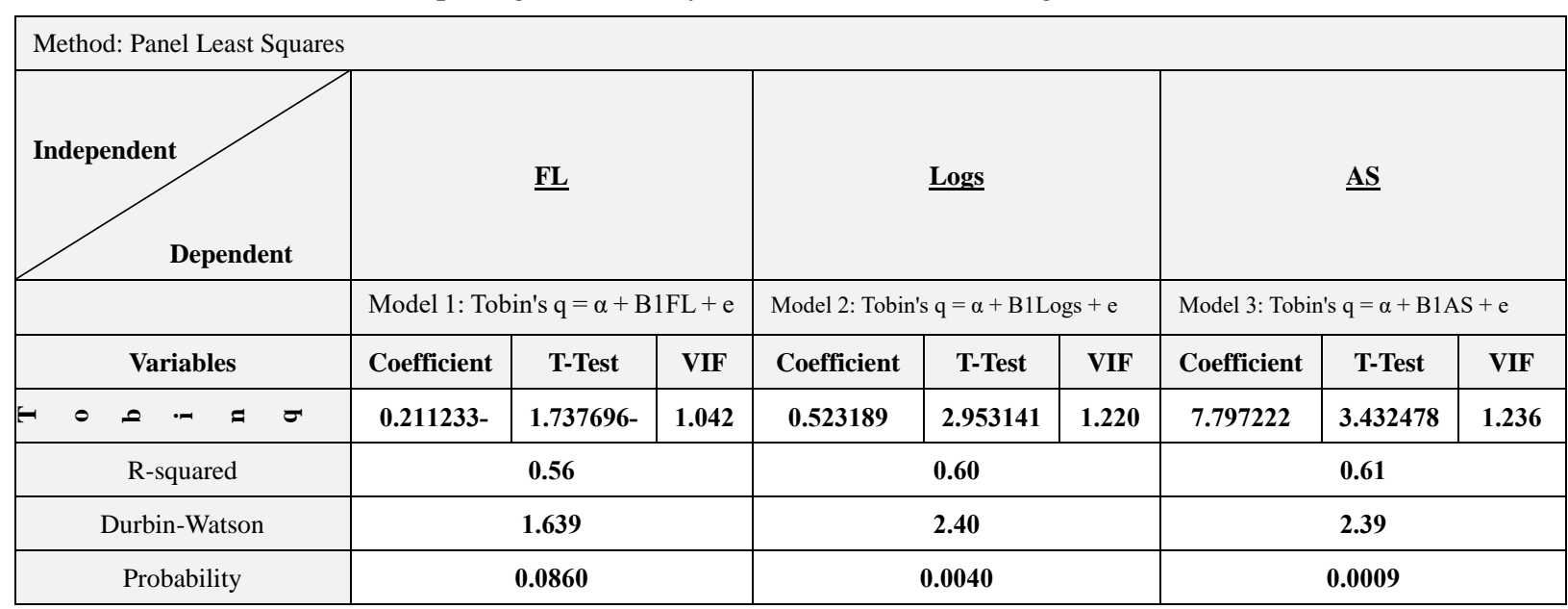

\section{Conclusions \& Recommendations}

The researcher concluded a group of conclusion as follows:

1. Jordan's mining and extraction industries sector does not focus on debt to increase the value of the firms.

2. Oversized companies enhance investor confidence in firm value.

3. Increase in asset structure, a positive indicator for investors.

4. There is no impact of financial leverage on the value of firms.

5. There is an impact of each of the size and assets structure on the value of the firms.

Based on the above mentioned conclusions, the researcher presented a group of recommendations as follows:

1. The study recommends that mining and extraction industries companies should link the concepts of financial leverage and the value of the firm and the attempt to combine them in a way that is reflected on profits.

2. Companies must achieve an optimal mixture of debt and equity, for long-term survival and hence the growth of the company.

3. New investors should measure corporate performance through asset structure and size, to make a successful investment decision.

4. Conducting more research on the same subject on different sectors, increasing sample companies, and other variables

The limitations of the study, the study is conducted on the sample of the Jordanian mining and extraction industry companies listed in the Amman Stock Exchange for the period 2010-2018. Therefore, the present study is valid for generalization within this sector only.

\section{References}

Aggarwal, D., \& Padhan, P. (2017). Impact of Capital Structure on Firm Value: Evidence from Indian Hospitality Industry. Theoretical Economics Letters, 7, 982-1000. https://doi.org/10.4236/tel.2017.74067

Agwan, A. A. (2015). An Empirical Analysis of Financial Leverage and its Components with Special Reference to Ultratech Cement Industry. International Journal of Research in Finance and Marketing, 5(4).

Ahmad, N., Salman, A., \& Shamsi, A. F. (2015). Impact of financial leverage of firm profitability: An investigation from cement sector of Pakistan. Research Journal of Finance and Accounting, 6(7), 68-74. Retrieved from https://www.iiste.org/Journals/index.php/RJFA/article/view/21594/22442

Akpinar, O. (2016). Does the use of derivatives affect firm value? Evidence from Turkey. Journal of transnational management, 21(2), 53-61. https://doi.org/10.1080/15475778.2016.1166998

Al-Ani, M. K. (2014). Effects of assets structure of the financial performance: evidence from sultanate of Oman. Journal of US-China Public Administration, 11(2), 170-179. Retrieved from https://www.researchgate.net/publication/278019169 
Al-Malkawi, H. A. N. (2008). Factors influencing corporate dividend decision: evidence from Jordanian panel data. International Journal of Business, 13(2), 177.

Al-Rdaydeh, M., Almansour, A., \& Al-Omari, M. (2018). Moderating effect of competitive strategies on the relation between financial leverage and firm performance: Evidence from Jordan. Business and Economic Horizons, 14(3), 626-641. https://doi.org/10.15208/beh.2018.44

Ayturk, Y., Curbuz, A. G., \& Yanik, S. (2016). Corporate derivatives use firm value: evidence from Turkey. Borsa Istanbul review, 16(2), 108-120. https://doi.org/10.1016/j.bir.2016.02.001

Ayuba, H., Bambale, A., Ibrahim, M., \& Sulaiman, S. (2019). Effects of Financial Performance, Capital Structure and Firm Size on Firms' Value of Insurance Companies in Nigeria. Journal of Finance, Accounting and Management, 10(1), 57-74.

Bestariningrum, N. (2015). Analyzing the Effect of Capital structure and Firm size on firm value (case study: Company That Listed in LQ-45 Index Period 2010-2014). Journal Berkala Ilmiah Efisiensi, 15(4), 354-365.

Cheryta, A. M., Moeljadi, \& Indrawati, N. K. (2017). The Effect of Leverage, Profitability, Information Asymmetry, Firm Size on Cash Holding and Firm Value of Manufacturing Firms Listed at Indonesian Stock Exchange. International Journal of Research in Business Studies and Management, 4(4), 21-31,

Chikalipah, S. (2019). Financial leverage and profitability of microfinance institutions. https://doi.org/10.3362/1755-1986.18-00009

Chung, K. H., \& Pruitt, S. W. (1994). A Simple Approximation of Tobin's q. Financial Management, 23(3), 70-74. https://doi.org/10.3362/1755-1986.18-00009

Collins, O., Filibus, I., \& Clement, A. (2012). Corporate Capital Structure and Corporate Market Value: Empirical Evidence from Nigeria. International Journal of Economics and Finance, 4(12), 193-201. https://doi.org/10.5539/ijef.v4n12p193

Desmintari, \& Yetty, F. (2016). Effect of profitability, Liquidity and assets structure on the company debt policy. International Journal of business and commerce, 5(6), 117-131. Retrieved from https://www.ijbcnet.com/5-6/IJBC-16-5612.pdf

Dutta, S., Mukherjee, T., \& Sen, S. (2018). Impact of Financial Leverage on the Value of Firm: Evidence from Some NSE Listed Companies. The BESC Journal of Commerce and Management, 4, 42-52. Retrieved from https://www.researchgate.net/publication/326693350

Faccio, M., Marchica, M. T., \& Mura, R. (2016). CEO gender corporate risk-taking and the efficiency of capital allocation. Journal of corporate finance, 39, 193-209. https://doi.org/10.1016/j.jcorpfin.2016.02.008

Farooq, M., \& Masood, A. (2016). Impact of Financial Leverage on Value of Firms: Evidence from Cement Sector of Pakistan. Research Journal of Finance and Accounting, 7(9), 73-77. Retrieved from https://www.iiste.org/Journals/index.php/RJFA/article/view/30307

Friend, I., \& Lang, L. H. (1988). An empirical test of the impact of managerial self-interest on corporate capital structure. Journal of Finance, 43, 217-281. https://doi.org/10.1111/j.1540-6261.1988.tb03938.x

Fu, L., Singhal, R., \& Parkash, M. (2016). Tobin's q Ratio and firm performance. International research Journal of Applied finance, 1(11), 1-10.

Gill, A., \& Obradovich, J. (2013). The Impact of Corporate Governance and Financial Leverage on the Value of American Firms. International Research Journal of Finance and Economics, 91, 1-14.

Harris, M., \& Raviv, A. (1991). The theory of capital structure. Journal of Finance, 46, 297-355. https://doi.org/10.1111/j.1540-6261.1991.tb03753.x

Ishari, M. P. (2016). The Impact of Financial Leverage on Firms' Value (Special Reference to Listed Manufacturing Companies in Sri Lanka). International Journal of Advancement In Engineering Technology, Management and Applied Science (IJAETMAS), 3(7), 100-104.

Jiricek, P., \& Dostalova, Z. (2010). Financial Management (2nd ed.).

Kim, J., Kwak, J., \& Lee, K. (2015). Estimating Tobin's Q for Listed Firms in Korea (1980-2005): Comparing Alternative Approaches and an Experiment with Investment Functions. Seoul Journal of Economics, 28(1), $1-29$.

Lindenberg, E. B., \& Ross, S. A. (1981). Tobin's q Ration and industrial organization. The Journal of business, 54(1), 1-32. https://doi.org/10.1086/296120 
Liow, K. H. (2010). Firm value, growth, profitability and capital structure of listed real estate: an international perspective. Journal of property research, 27(2), 119-146. https://doi.org/10.1080/09599916.2010.500459

Machali, M., \& Setiadharma, S. (2017). The effect of assets structure and firm size on firm value with capital structure as intervening variables. Journal of business and financial affairs, 6(4), 2-5.

Modigliani, F., \& Miller, M. H. (1958). The Cost of Capital, Corporation Finance and The Theory of Investment. American Economic Review, 48(3), 261-297.

Moeljadi. (2014). Factors affecting firm value: theoretical study on public manufacturing firm in Indonesia. South East Asia Journal of Contemporary Business, Economics and Law, 5(2), 6-15. Retrieved from https://seajbel.com/previous-issues/december-2014/vol-5-issue-2-june-2014-bussiness/

Mule, R. K., \& Mukras, M. S. (2015). Financial leverage and performance of listed firms in a frontier market: Panel evidence from Kenya. European Scientific Journal, 11(7), 171-184.

Myers, S. C. (1977). Determinants of corporate borrowing. Journal of Financial Economics, 5, 147-175. https://doi.org/10.1016/0304-405X(77)90015-0

Myers, S. C. (2002). Capital structure. Journal of Economic Perspectives, 15(2), 81-102. https://doi.org/10.1257/jep.15.2.81

Noghondari, A. T., \& Noghandari, A. T. (2017). The Mediation Effect of Financial Leverage on the Relationship between Ownership Concentration and Financial Corporate Performance. Iranian Journal of Management Studies, 10(3).

Panaretou, A. (2014). Corporate risk management and firm value: evidence from the U.K market. The European Journal of finance, 20(12), 1161-1186. https://doi.org/10.1080/1351847X.2013.766625

Pandey, I. M. (2015). Financial management (11th ed.). New Delhi, India: Vikas Publishing House PVT Ltd.

Raheel, T., \& Shah, F. M. (2015). A study that identify the relationship between the financial leverage and firm's profitability: empirical evidence from oil and Gas companies of Pakistan listed in KSE. International Journal of Scientific and engineering research, 6(11), 80-88. Retrieved from https://www.ijser.org/research-paper-publishing-november-2015.aspx

Rajan, R. G., \& Zingales, L. (1995). What do we know about capital structure? Some evidence from international data. Journal of Finance, 50, 1421-1460. https://doi.org/10.1111/j.1540-6261.1995.tb05184.x

Rayan, K. (2008). Financial Leverage and firm value, master published thesis (Degree of Master of Business Administration). Gordon institute of business science, university of Pretoria.

Raza, M. W. (2013). Effect of financial leverage on firm performance. Empirical evidence from Karachi Stock Exchange (No. 50383). University Library of Munich, Germany.

Sabrin., Sarta, B., Takdir D. S., \& Sujono. (2016). The effect of profitability on firm value in manufacturing company at Indonesia stock exchange. The international journal of engineering and science, 5(10), 81-89. Retrieved from http://www.theijes.com/papers/v5-i10/K0501081089.pdf

Senol, Z., Karaca, S. S., \& Erdogan, S. (2017). The effect of financial risk management on firm value: An empirical evidence from Borsa Istanbul Stock Exchange. Financial Studies, 4.

Titman, S., \& Wessles, R. (1988). The determinants of capital structure choice. Journal of Finance, 43, 1-19. https://doi.org/10.1111/j.1540-6261.1988.tb02585.x

Ukhriyawati, C. F., Ratnawati, T., \& Riyadi, S. (2017). The Influence of Asset Structure, Capital Structure, Risk Management and Good Corporate Governance on Financial Performance and Value of The Firm through Earnings and Free Cash Flow As An Intervening Variable in Banking Companies Listed in Indonesia Stock Exchange. International Journal of Business and Management, 12(8), 249-260. https://doi.org/10.5539/ijbm.v12n8p249

Williamson, O. E. (1988). Corporate finance and corporate governance. Journal of Finance, 43(3), 567-591. https://doi.org/10.1111/j.1540-6261.1988.tb04592.x

\section{Copyrights}

Copyright for this article is retained by the author(s), with first publication rights granted to the journal.

This is an open-access article distributed under the terms and conditions of the Creative Commons Attribution license (http://creativecommons.org/licenses/by/4.0/). 